\title{
High genetic diversity in population of Lepturichthys fimbriata from the Yangtze River revealed by microsatellite DNA analysis
}

\author{
ZHANG FuTie $^{1}$, DUAN YouJian ${ }^{1,2}$, CAO ShanMao ${ }^{2}$, WANG JianWei ${ }^{1}$ \& TAN DeQing ${ }^{1 *}$ \\ ${ }^{1}$ Key Laboratory of Aquatic Biodiversity and Conservation of Chinese Academy of Sciences, Institute of Hydrobiology, Chinese Academy of \\ Sciences, Wuhan 430072, China; \\ ${ }^{2}$ Dalian Ocean University, Dalian 116023, China
}

Received April 16, 2011; accepted July 22, 2011

\begin{abstract}
Lepturichthys fimbriata (Günther) is one of the benthic and rock-attached fish species that is typically found in torrential flows of the upper reaches of the Yangtze River in China. Several dams in the Yangtze River (the Ertan Dam, the Three Gorges Dam, the Gezhouba Dam, the Xiluodu Dam and the Xiangjiaba Dam (the latter two dams are under construction)) may have significant effects on the habitat and spawning behaviors of L. fimbriata, and could ultimately threaten the survival of this fish. We studied the population genetic diversity of L. fimbriata samples collected at three sites within the Yangtze River and one of its tributaries, the Yalong River. Genetic diversity patterns were determined by analyzing genetic data from 14 polymorphic microsatellite loci isolated in Jinshaia sinensis (Sauvage et Dabry). A high genetic diversity among these L. fimbriata local populations was indicated by the number of microsatellite alleles $(A)$ and the expected heterozygosity. No reductions of genetic diversity in any $L$. fimbriata population were observed. However, significant population differentiations were observed among three local populations by pairwise comparisons $(P<0.001)$. We deduced that $L$. fimbriata local populations were not small ones. In addition, the habitat behaviors of rock-attachment and possible residence of L. fimbriata could account for the genetic differences found in local populations.
\end{abstract}

Lepturichthys fimbriata, microsatellite, genetic diversity, genetic differentiation

Citation: Zhang F T, Duan Y J, Cao S M, et al. High genetic diversity in population of Lepturichthys fimbriata from the Yangtze River revealed by microsatellite DNA analysis. Chin Sci Bull, 2012, 57: 487-491, doi: 10.1007/s11434-011-4704-8

Lepturichthys fimbriata (Günther), belonging to Balitoridae (Homalopteridae) in the Cypriniformes, is a small-sized freshwater fish of the upper Yangtze River of China. It is a benthic fish, typically found in rivers with torrential flow. They habitually form schools and produce pelagic eggs from mid-April to mid-June every year. Their spawning fields lie in the gorges with dramatic water level changes and quickwater of the middle and lower reaches of the Jinsha River (another name for the upper reaches of the Yangtze River above the Yibin segment) and the lower reaches of the Yalong River, a tributary of the Jinsha River. The eggs and larval fish drift downstream, with some larvae reaching the middle reaches of the Yangtze River down-

*Corresponding author (email: dqtan@ihb.ac.cn) stream of Yichang [1-3].

Three dams lacking fishways have now been constructed within the habitat and spawning fields of L. fimbriata along the Yangtze River and the Yalong River. The Ertan Dam, constructed from 1991 to 2000, is in the down reaches of the Yalong River. The Gezhouba Dam, built from 1974 to 1988 , is in the middle segment of the Yangtze River in Yichang. The Three Gorges Dam, constructed from 1994 to 2006, is also in Yichang, just $38 \mathrm{~km}$ upstream of the Gezhouba Dam. Another two dams (the Xiluodu Dam and the Xiangjiaba Dam) are now being constructed in the main spawning field of L. fimbriata along the lower reaches of the Jinsha River (Figure 1). The Xiluodu Dam, which started in Dec. 2005, was initially dammed in Nov. 2007. The Xiangjiaba Dam, which started in Dec. 2006, was initially 


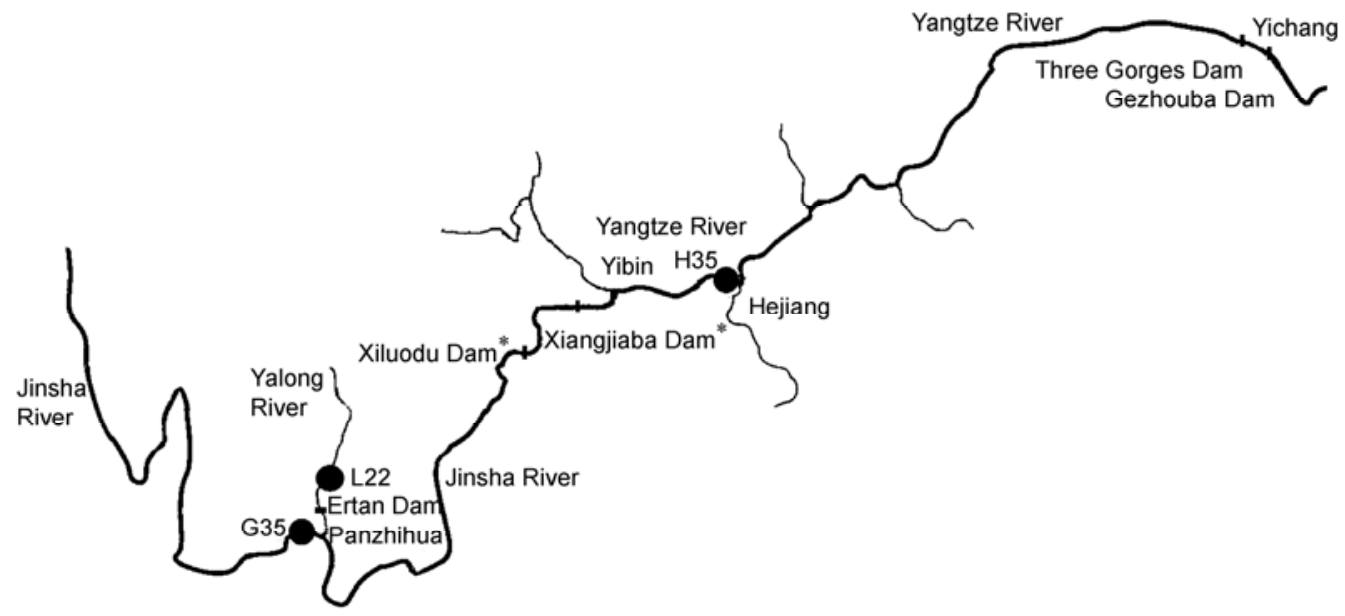

Figure 1 Map of the Yangtze River and its tributaries, showing approximate sampling locations (by circles) and dams (by rectangles, with those under construction marked by an asterisk).

dammed in Dec. 2008. These hydro-projects have dramatically changed the hydrological conditions in the upper and middle reaches of the Yangtze River, and have also changed the environments of the habitat and spawning fields of $L$. fimbriata. Such changes could ultimately threaten the survival of this fish.

There is an urgent need to conserve the biodiversity of the threatened fish. However, little is known about the genetic diversity of $L$. fimbriata. Recently, microsatellite DNA markers from another Balitoridae, Jinshaia sinensis (Sauvage et Dabry), have been successfully isolated [4]. In this study, we sought to elucidate the patterns of genetic diversity of the natural population of L. fimbriata and differentiation among population samples of $L$. fimbriata, as determined by genetic data from 14 polymorphic microsatellite loci isolated from $J$. sinensis. The potential effects of the dams on the habitat and genetic structure of L. fimbriata were analyzed.

\section{Materials and methods}

\subsection{Sampling}

During the spring from Apr. to May of 2009, L. fimbriata was sampled at three sites along the Yangtze River and the Yalong River (Figure 1, Table 1). Depending on watercourse size, fish were collected using gill nets or dipnets. Fin clips were stored in 95\% ethanol. Fish samples were confirmed to be of the right species based on photographs and specimens.

\subsection{DNA extraction and microsatellite analysis}

Genomic DNA extraction was conducted according to the method described by Aljanabi and Martinez [5] with some modifications noted by Zhang and Tan [6]. Finally, DNA was resuspended in $100-200 \mu \mathrm{L}$ of $1 \times \mathrm{TE}(10 \mathrm{mmol} / \mathrm{L}$ Tris, $1 \mathrm{mmol} / \mathrm{L}$ EDTA) and visually inspected for quality and quantity on $0.8 \%$ agarose gels.

Twenty-one microsatellite DNA loci were amplified using a PCR procedure. Primers for these 21 microsatellites were synthesized according to the submitted sequences of $J$. sinensis on GenBank (HQ849523-HQ849543). PCR was performed in $20 \mu \mathrm{L}$ reactions consisting of $1 \times \mathrm{PCR}$ buffer, 1.0-3.0 mmol/ $/ \mathrm{L} \mathrm{MgCl} 2,0.1 \mathrm{mmol} / \mathrm{L}$ dNTPs (Amresco), 0.2 $\mu \mathrm{mol} / \mathrm{L}$ primers, $0.3 \mathrm{U}$ Taq DNA polymerase (Fermentas), and about 20 ng genomic DNA. The basic thermocycling program was $94^{\circ} \mathrm{C}$ for $4 \mathrm{~min}$; then 35 cycles at $94^{\circ} \mathrm{C}$ for $30 \mathrm{~s}, \mathrm{~N}^{\circ} \mathrm{C}$ ( $\mathrm{N}$ is the annealing temperature) for $40-60 \mathrm{~s}$, and $72^{\circ} \mathrm{C}$ for $60 \mathrm{~s}$; with a final step at $72^{\circ} \mathrm{C}$ for $10 \mathrm{~min}$. PCR products were electrophoresed on nondenaturing $8 \%$ polyacrylamide gels (Ais:Bis=29:1) on Sequi-Gen GT system (Bio-Rad).

The gels were Ethidium bromide-stained and the allele sizes were obtained by manually comparing the alleles' sizes with pBR322 DNA/Msp I and pUC18 DNA/Msp I markers (Tiangen). Only intensely stained, unambiguous, clear bands were counted. Genotypes were checked for scoring errors attributable to stutter-products, large allele drop-out, or null alleles, using Micro-Checker v2.2.3 [7].

Table 1 Description of sites and samples

\begin{tabular}{lccc}
\hline Site & River & Sample size & Abbreviation \\
\hline Lizhuang, Yanyuan County, Sichuan Province & Yalong River & 22 \\
Guanyingyan, Panzhihua, Sichuan Province & Jinsha River & 35 \\
Hejiang Town, Hejiang County, Sichuan Province & Yangtze River & 35 & G35 \\
\hline
\end{tabular}




\subsection{Data analysis}

Number of alleles $(A)$, expected and observed heterozygosity ( $H E$ and $H O$, respectively), and genetic distances were compiled using Popgene software v1.32 [8]. Standardized allelic richness $(A r)$ and $F$-statistics $\left(F_{\mathrm{ST}}\right.$ and $\left.F_{\text {IS }}\right)$ were estimated using Fstat software v2 9.3.2 [9]. $F$-statistics were also computed by Arlequin software v3.1 [10]. A Bonferroni correction was used for multiple testing [11].

\section{Results}

\subsection{Population genetic diversity in L. Fimbriata}

Among 21 pairs of microsatellite primers of J. sinensis, 14 pairs (JS03, JS08, JS15, JS22, JS24, JS27, JS28, JS29, JS31, JS34, JS35, JS38, JS56 and JS63) were successfully amplified in L. fimbriata. Microsatellite DNAs of 92 L. fimbriata fish from three locations were analyzed, in which all 14 microsatellite loci were found to be polymorphic, with the number of alleles per locus ranging from 13 to 33 (mean = 21.3). Allelic richness ranged from 5.521 to 19.415 . The $H O$ was from 0.8485 to 1.0000 (mean $=0.8667-1.0000$ ), while the $H E$ ranged from 0.7579 to 0.9590 (mean = 0.8534-0.9455) (Table 2). Null alleles were checked by Micro-Checker. There was no evidence of large allele dropout, null alleles, or scoring errors caused by stuttering through the 14 polymorphic microsatellite loci.

\subsection{Population genetic differentiation in L. Fimbriata}

Pairwise comparisons among populations indicated that the population genetic distance ranged from 0.2538 to 0.3576 (Table 3). The similarity between L22 and H35 populations was the lowest, while the L22 population was the most similar to the G35 population, with the smallest genetic distance.

$F$-statistics were computed by both Fstat and Arlequin software, and no conflicting results appeared. $F_{\text {IS }}$ values ranged from -0.1918 to 0.0754 , and no local populations were observed to have departed from the Hardy-Weinberg equilibrium across all loci. However, in the whole population, locus JS24 was observed to significantly depart from the Hardy-Weinberg equilibrium $(P<0.05)$ (Table 2$)$. Thus in the next analysis, the JS24 locus was excluded.

Genetic differentiations $\left(F_{\mathrm{ST}}\right)$ at 13 polymorphic loci (except JS24) among all populations were $0.0202(P=$ $0.00000, \mathrm{G} 35$ vs. H35), 0.0238 ( $P=0.00000, \mathrm{~L} 22$ vs. H35), and $0.0248(P=0.00000, \mathrm{~L} 22$ vs. G35), as determined by pairwise comparisons (Table 4$)$.

\section{Discussion}

Sequences flanking microsatellite motifs in closely related organisms are highly conserved; therefore microsatellite loci of one species may be applied in other related species $[12,13]$. In this study, 14 of the 21 pairs of primers from $J$. sinensis showed successful cross-species amplification in $L$. fimbriata.

We then examined the genetic diversity of L. fimbriata populations at different locations along the Yangtze River by microsatellite DNA analysis. The 14 microsatellite loci were found to be highly polymorphic, with a mean value of $21.3 A$ per locus and per population. Besides the average $A$, the $H E$ is also generally used as an indicator of genetic diversity [14], and the value of HE across 14 loci in this study was very high $(H E=0.9132)$ (Table 2$)$. Microsatellite variation in 78 species of both freshwater and marine fishes was compared and values of $H E=0.58$ and $A=7.1$ for freshwater fishes was observed by DeWoody and Avise [14]. DeWoody and Avise's $H E$ and $A$ values are far lower than those obtained for L. fimbriata, suggesting that L. fimbriata has a naturally higher genetic diversity.

Furthermore, no obvious declines in genetic diversity were noted in the dam-blocked population L22 ( $H E=$ 0.8882 and $A=12.4)$, when compared with other unblocked populations, such as G35 $(H E=0.8998$ and $A=15.8)$ and H35 ( $H E=0.9054$ and $A=15.9$ ) (Table 2). No heterozygote deficits were detected in any of the 3 populations (the negative $F_{\text {IS }}$ mean values in Table 2 ). Unlike the potamodromous (or anadromous) and relatively long-lived fishes, such as bull trout (Salvelinus confluentus) [15], catostomids $[16,17]$, and largemouth bronze gudgeon (Coreius guichenoti Sauvage et Dabry) [6], L. fimbriata has a relatively early age of maturity and a short lifespan $[3,18]$. The phenomena of inbreeding and genetic drift usually happen in a small population but not in a large one $[15,19]$, which provides one possible reason for the maintenance of genetic diversity after about 10 years isolation between L22 and the other populations, in that there are sustainably large amounts of L. fimbriata fish in the Yalong River above the Ertan Dam.

However, significant genetic differentiation was observed in all local L. fimbriata populations by pairwise comparisons $(P<0.001)$ (Table 4$)$. L. fimbriata adults are usually attached to the rocks of the riverbed and infrequently migrate from one place to another $[1,3,18]$; thus, geographical variations and significant genetic differentiations between local populations unavoidably exist, which agrees with the conclusions of other studies $[18,20]$. Usually, habitat fragmentations caused by dams or sand bars and other interventions accelerate the population genetic differentiation of blocked fishes [6,15,21]; surprisingly, we observed no obvious differences in the values of $F_{\mathrm{ST}}$ from pairwise comparisons of the three populations (Table 4). To this rock-attached and possible resident fish L. fimbriata [3,18], the effects caused by dam blockage might be temporarily shaded by effects from its peculiar habitat behavior. More samples from local population and more elaborate experiments are required to further elucidate this issue. 


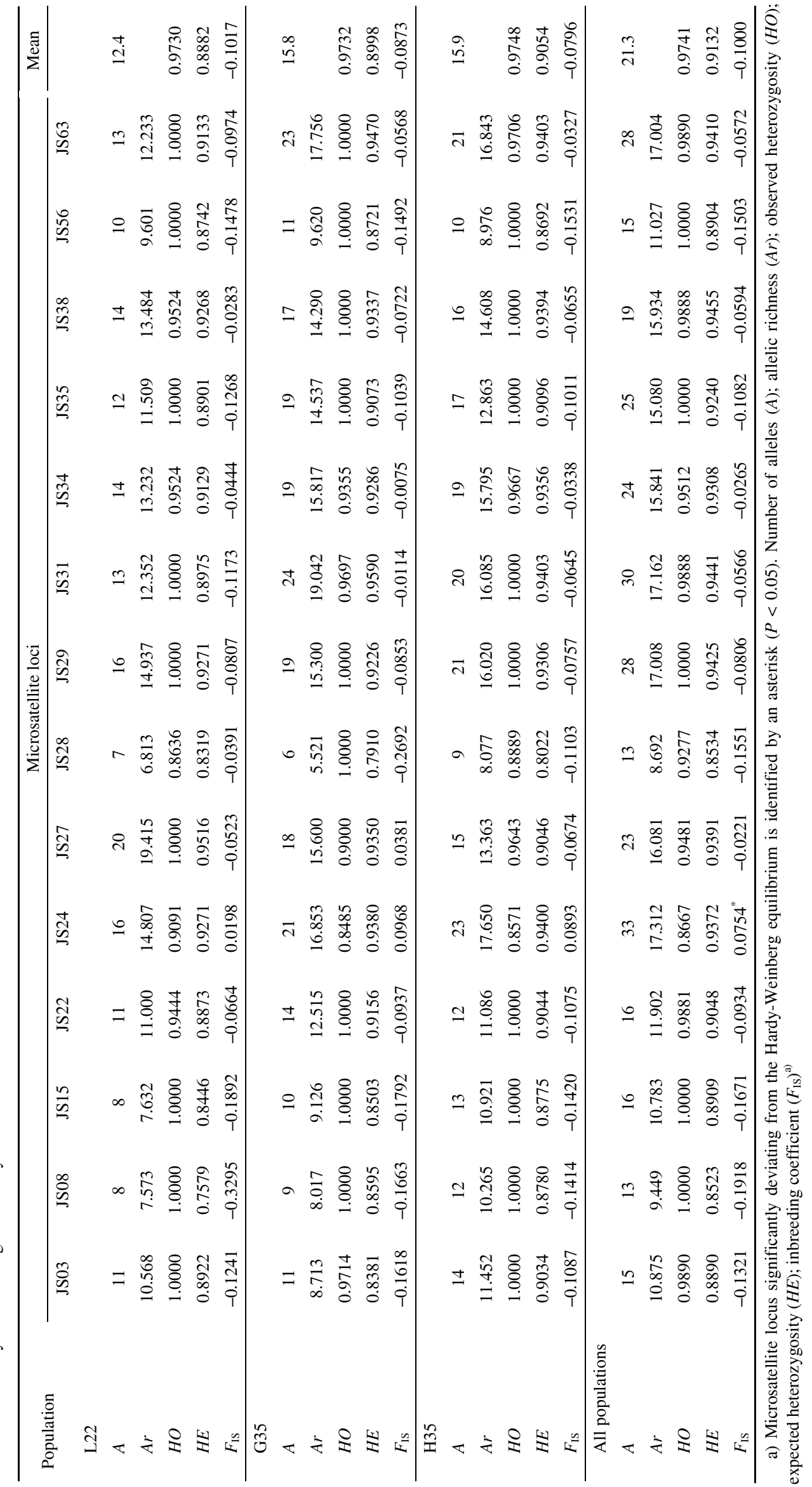


Table 3 Nei's unbiased genetic distance analyzed by Popgene software

\begin{tabular}{ccc}
\hline & L22 & G35 \\
\hline G35 & 0.2538 & \\
H35 & 0.3576 & 0.3305 \\
\hline
\end{tabular}

Table 4 Pairwise $F_{\text {ST }}$ values (except JS24) between three L. fimbriata populations compiled by Arlequin and Fstat software ${ }^{\text {a) }}$

\begin{tabular}{cccc}
\hline & L22 & G35 & H35 \\
\hline L22 & & 0.00000 & 0.00000 \\
G35 & 0.0248 & & 0.00000 \\
H35 & 0.0238 & 0.0202 & \\
\hline
\end{tabular}

a) Below the diagonal, $F_{\mathrm{ST}}$; above the diagonal, $P$ values.

The spawning fields of $L$. fimbriata mainly span from the middle reaches of the Jinsha River to the section of the Yangtze River above Yibin and downstream of the Yalong River. The Ertan Dam has separated the Yalong spawning stocks from the others, and additional dams - the Xiluodu Dam and the Xiangjiaba Dam - are being constructed in the lower reaches of the Jinsha River (Figure 1), which will likely completely break up the main spawning fields. This may pose a serious threat to the survival of L. fimbriata in the Yangtze River. Our findings provide a good starting point to study the effect of man-made interventions like dams on the fragile ecosystem of fishes in our rivers, and the conservation of, and further research, on the Balitoridae fish in the future.

\section{Conclusions}

In this study, we elucidated the genetic diversity of the whole natural population of L. fimbriata using 14 polymorphic microsatellite loci isolated from $J$. sinensis. The high genetic diversity among three $L$. fimbriata local populations was indicated by the number of microsatellite alleles and the expected heterozygosity. No reductions in genetic diversity were observed in any L. fimbriata population. However, significant population differentiations were observed among 3 populations by pairwise comparisons $(P<0.001)$. We deduced that $L$. fimbriata local populations were not small populations. In addition, the habitat behaviors of rock-attachment and possible residence of $L$. fimbriata could account for the genetic differences found in local populations.

The authors thank Mr. DAN ShengGuo for the sample collection. This work was supported by joint funds of the National Natural Science Foundation of China and Yalong River Hydropower Development Foundation (50679095), China Yangtze Three Gorges Project Development Corporation (0714086) and Non-profit Industry Financial Program of MWR of China (200901011).
1 Li H D. Observation on reproductive and postembryonic development of Lepturichthys guntheri Hora (in Chinese). Chinese J Zool, 1965, 2: 79-83

2 Institute of Hydrobiology, Hubei Province. Fishes of the Yangtze River (in Chinese). Beijing: Science Press, 1976

3 Ding R H. The Fishes of Sichuan (in Chinese). Chengdu: Sichuan Publishing House of Science and Technology, 1994

4 Duan $\mathrm{Y}$, Zhang $\mathrm{F}$, Cao $\mathrm{S}$, et al. Isolation and characterization of polymorphic microsatellite loci in Jinshaia sinensis (in Chinese). Acta Hydrobiol Sin, 2011 (in press)

5 Aljanabi S M, Martinez I. Universal and rapid salt-extraction of high quality genomic DNA for PCR-based techniques. Nucleic Acids Res, 1997, 25: 4692-4693

6 Zhang F, Tan D. Genetic diversity in population of Largemouth Bronze Gudgeon (Coreius guichenoti Sauvage et Dabry) from Yangtze River determined by microsatellite DNA analysis. Genes Genet Syst, 2010, 85: 351-357

7 Van Oosterhout C, Hutchinson W F, Wills D P M, et al. MicroChecker: Software for identifying and correcting genotyping errors in microsatellite data. Mol Ecol Notes, 2004, 4: 535-538

8 Yeh F C, Yang R C, Boyle T B J, et al. POPGENE, the user-friendly shareware for population genetic analysis. Molecular Biology and Biotechnology Centre, University of Alberta, Canada. 1997

9 Goudet J. FSTAT, a program to estimate and test gene diversities and fixation indices (version 2.9.3). 2001

10 Excoffier L, Laval G, Schneider S. Arlequin ver. 3.0: An integrated software package for population genetics data analysis. Evol Bioinform, 2005, Online 1: 47-50

11 Rice W R. Analyzing tables of statistical tests. Evolution, 1989, 43: 223-225

12 Schlotterer C, Amos B, Tautz D. Conservation of polymorphic simple sequence in cetacean species. Nature, 1991, 354: 63-65

13 Tong J, Wang Z, Yu X, et al. Cross-species amplification in silver carp and bighead carp with microsatellite primers of common carp. Mol Ecol Notes, 2002, 2: 245-247

14 DeWoody J A, Avise J C. Microsatellite variation in marine, freshwater and anadromous fishes compared with other animals. J Fish Biol, 2000, 56: 461-473

15 Neraas L P, Spruell P. Fragmentation of riverrine systems: The genetic effects of dams on bull trout (Salvelinus confluentus) in the Clark Fork River system. Mol Ecol, 2001, 10: 1153-1164

16 Whitehead A, Anderson S L, Kuivila K M, et al. Genetic variation among interconnected populations of Catostomus occidentalis: Implications for distinguishing impacts of contaminants from biogeographic structuring. Mol Ecol, 2003, 12: 2817-2833

17 Lippe C, Dumont P, Bernatchez L. High genetic diversity and no inbreeding in the endangered copper redhorse, Moxostoma hubbsi (Catostomidae, Pisces): The positive sides of a long generation time. Mol Ecol, 2006, 15: 1769-1780

18 Chen Y Y. Systematic studies on the fishes of the family homalopteridae of China III. Phyletic studies of the homalopterid fishes (in Chinese). Acta Zootaxonom Sin, 1980, 5: 200-211

19 Therkildsen N O, Nielsen E E, Swain D P, et al. Large effective population size and temporal genetic stability in Atlantic cod (Gadus morhua) in the southern Gulf of St. Lawrence. Can J Fish Aquat Sci, 2010, 67: 1585-1595

20 Chen Y Y, Cao W X, Zheng C Y. Ichthyofauna of the Zhujiang River with a discussion on zoogeographical divisions for freshwater fishes (in Chinese). Acta Hydrobiol Sin, 1986, 10: 228-236

21 McCraney W T, Goldsmith G, Jacobs D K, et al. Rampant drift in artificially fragmented populations of the endangered tidewater goby (Eucyclogobius newberryi). Mol Ecol, 2010, 19: 3315-3327

Open Access This article is distributed under the terms of the Creative Commons Attribution License which permits any use, distribution, and reproduction in any medium, provided the original author(s) and source are credited. 